\title{
Form-based Approaches vs. Task-Based Approaches
}

\author{
Zahra Talebi (Corresponding author) \\ Islamic Azad University, Ahar Branch, Iran \\ E-mail: Zahra.talebi04@gmail.com \\ Nader Assadi Aidinlou \\ Islamic Azad University, Ahar Branch, Iran \\ Sima Farhadi \\ Islamic Azad University, Ahar Branch, Iran
}

Received: 05-12- 2014

Published: 01-07- 2015
Accepted: 08-02- 2015

doi:10.7575/aiac.ijalel.v.4n.4p.137 URL: http://dx.doi.org/10.7575/aiac.ijalel.v.4n.4p.137

\begin{abstract}
This study aimed at investigating whether task-based approaches bear any superiority to that of more traditional ones evident in presentation-practice- and production phase .to fulfill the purpose of the study, the participants within the age range of 11-19, took part in the study. Following a pretest, treatment, and a posttest, the obtained data was analyzed using analysis of covariance (ANCOVA) to examine the effects of the variables. The results of the analysis showed that participants in the PPP group did significantly better in the grammar recognition of the posttest than that of the task group. However, their counterparts in the task group gained better scores in the writing section of the test this research study provided evidence in support of task proponents' claim in the merit of task-based activity in raising learners' implicit knowledge claiming to play the primary role in spontaneous speech.
\end{abstract}

Keywords: Task-based language teaching, PPP model, focus on form, focus on meaning

\section{Introduction}

The communicative approach has dominated English language teaching. It has firmly established itself in ESL-based contexts where learners have enough opportunities to put into practice the formal aspects of language under real operating conditions. However, a great deal of L2 learning occurs in EFL contexts where learners mostly have to be preoccupied with grammatical properties of language which is more evident in structural oriented approaches of which PPP is a typical example. PPP standing for presentation, practice, and production consists of the following three stages: a) presentation phase: the teacher presents a grammatical rule and illustrates its meaning. b) Practice phase: participants of the study practice items under teacher control activities, and c) production phase: learners produce the items in more communicative-based activities such as role play, stimulation and conversations (Willis and Willis, 2007). However, when involved in a meaningful activity, learners seem to be at a loss to carry over the acquired structures in their production.

The shortcomings associated with such traditional form-based approaches led interactionist hypothesis advocators to contend that learners acquire a second language best when their attention is focused on meaning rather than language forms. Very soon this approach attracted a number of researchers (Krashen, 1982; Krashen \& Terrel, 1983; Prabhu, 1987).

However, gradually waves of criticism revealed that, meaningful communication which focuses solely on meaning processing are not adequate for learning a second language. In order to strike a balance between meaning and form and in order to get the best of two worlds, 'task' was proposed as the desired solution (see e.g., Prabhu, 1987; Skehan ,1996; Ellis, 2003; Nunan, 2004). 'Task' seems to be an appropriate candidate for engaging learners in using language pragmatically, where the primary attention is devoted to meaning and any formal acquisition that occurs during conversing with an interlocutor is incidental (Ellis , 2003). The claim put forward by TBLT advocates in the superiority of this approach over other traditional ones have rarely been touched. This study is an attempt to tackle the issue and investigate the TBLT proponents' claim in efficiency of task in delivering what their proponents promise.as Ellis suggests, the general goal of language learning, unlike what is perceived in traditional approaches, is not to make learners accumulate a pile of knowledge 'about' language but to enable them to make use of it for communication purposes.

The current study attempts to (dis)confirm the claim put forward by TBLT advocates (i.e., the advantage of TBLToriented approaches to the other more form-based ones).

The following tentative research questions have been formed for which the current study seeks to find answer. 
RQ1: Is there any significant difference between the performance of PPP and task-bases group members in grammar test?

RQ2: Is there any significant difference between the performance of PPP and task-bases group members in writing activity?

The following hypotheses are put forward for the above research questions:

$\mathrm{H} 1$ : there is not any significant difference between the performance of PPP and task-based group members in grammar test.

$\mathrm{H} 2$ : there is not any significant difference between the performance of PPP and task-based group members in writing activity.

\section{Literature Review}

In the $1990 \mathrm{~s}$, researchers began to pay more attention to grammar instruction in the classroom where it has taken on various roles in second and foreign language instruction. In the style in which the classical languages (Latin \& Greek) were taught, grammar teaching formed an essential part of language instruction which led to focus on forms. Focus on forms is defined as "an occasional shift of attention to linguistic code features- by the teacher and/or one or more students- triggered by perceived problems with Comprehension or production" (Long \& Robinson, 1998, P.23). Within this type, there is obviously no communicative context. However a glance through the last decades of languageteaching practices in the field of second language acquisition reveals a shift of attention from purely linguistic to more communicative approaches (Brown, 2001). During the last decades some researchers attempt to abandon the grammaraccuracy tenet in favor of more communicatively-oriented approaches that focused on language use and functions, without any form of grammar instruction. According to Nassaji \& Fotos (2004) traditional methods on isolated grammar forms were not sufficient to promote learners' acquisition in second language. The communicative language Teaching (CLT) proponents advocated that second language acquisition is driven by exposure to positive Evidence and comprehensible input without any need for corrective feedback (e.g., Allwright, 1975; Krashen \& Terrell, 1983; Krashen, 1985, 1994, 1998; Prabhu, 1987; Dulay \& Burt, 1973; Gass, 1997).However, most of the researchers, consider positive evidence and communicative activities which focus solely on meaning processing are not adequate for learning a second language (e.g., Hatch, 1978; Long, 1983, 1996, 1997; White, 1987). Therefore, in order to keep the two opposing poles of language, i.e. form and meaning, language teaching professionals (Prabhu, 1987; Skehan, 1996; Ellis, 2003; Nunan, 2004) suggested task as the desired solution, claiming that task provides the ideal condition for L2learning and caters both for form and meaning. By provision of opportunities for learners to engage in meaningful communication, learners are believed to enhance their communicative competence, and drawing attention to specified forms employed in the course of communication increases the likelihood of their internalization by learners.

\subsection{Task-oriented studies}

Skehan (2003), comments that "although there are still areas of disagreement within task research, there has been significant progress in developing better performance measures. The complexity-accuracy-fluency dimensions of task performance have been justified both theoretically and empirically" (p.8).

Kim (2009) investigated the impact of task complexity on the occurrence of language related episodes with thirty four ESL learners in two different tasks. Two groups of learners with different level of complexity performed four tasks. Kim's findings partially confirmed Robinson's Hypothesis claiming more cognitively demanding task leads to more negotiation of meaning and language related episodes( LREs) dvocates of strong version of TBLT (see e.g. Krashen, 1982; Willis and Willis, 1998) view task as a necessary and a sufficient condition for L2 learning. To them, no explicit grammar instruction is required in stretching learners' interlanguage and task can be incorporated into the syllabus as a unit of teaching in its own right. Vilches (2003) points out that the changes in the syllabus of the university produced a positive effect on learners' proficiency compared to that of former syllabus. Interested in investigating which writing task, (a composition task, an editing task, or a text reconstruction task) generates the greatest amount of grammar attention. Storch (2001) assigned tertiary second language learners to one of the above conditions. He conceptualized focus on grammar as the frequency of LREs observed in leraners' production. Participants in the composition task were required to write a composition based on a diagram; editing task learners were presented with a text containing grammatical errors and instructed to correct them; and the third group was given a text which comprised content words, where learners were asked to provide necessary function words.

His findings revealed that text reconstruction task was more successful in eliciting form focused episodes than the other form of editing task. Foster and Skehan (1999) compared the different foci of planning in two different groups. Their study revealed that, preplanning had a significant effect on learners' production based on fluency, accuracy, and complexity. Among the three groups of planners, the teacher-fronted ones had the highest score in accuracy and achieved a high score in complexity. They concluded that teachers play a facilitative role in pre-planning phase. Regarding the second point of the study, that is focus on planning, the groups did not differ from one another significantly. Mayo (2002), attempted to find out which kind of activity was most successful in eliciting focus on form in meaningful interaction. The study indicated that the editing task was the most successful one due to its nature of presentation. A number of studies with different aspects of task have been investigated. However, no study was found to specifically investigate the efficacy of TBLT and its superiority to other structurally-oriented models particularly in an EFL context. Therefore, a need is felt to investigate the claim put forward by task proponents (Prabhu, 1987; Skehan, 1996; Ellis, 2003; Littlewood, 2004; Nunan, 2004) in advantages they claim task enjoys compared with PPP model. 


\section{Methodology}

\subsection{Participants}

The participants of current study were thirty pre-intermediate female learners from two intact classes. The number of participants in both the control (PPP) and experimental (task-supported) group was fifteen.

\subsection{Instruments}

Instruments used in this study were a grammar recognition test and a writing task to elicit required structure from the participants once as a pretest and as a posttest. The grammar recognition test consisted of thirty question items. The questions were taken from Top Notch textbook and workbook. After the grammar recognition test, learners were involved in a writing task as a productive activity to investigate learners' ability to engage in a meaningful activity. All the items of the grammar recognition test targeted Simple Past Tense, Simple Present Tense, Present Continuous Tense, and There is/ There are/ How much/How many structure which were the focus of treatment.

Two texts were used to function as the primary source of input and as the secondary source of input for the task group and control group. Text A consisted of 250 words and 20 tokens of the target form. Text B comprised 200 words and 16 tokens of the target form. Another 120-word easy passage had 18 tokens of simple present tense to function as a dictogloss task.

For instructing present continuous tense, There is/ There are/ How much/How many structure in the task group, learners received a picture sequence pictures were chosen to meet the objectives of using target forms. Since learners were not able to see their partners 'pictures, they had to negotiate with each other and determine the difference between two pictures.

\subsection{Procedure}

The experiment lasted for ten sessions of instruction eight of which were devoted to instruction and two, to conducting pre-test and post-tense. The experimental group received the treatment through tasks and the control group, through PPP model.

Fifteen participants formed the experimental group. The presented task targeting the structure of simple past tense was an information gap activity in which each pair of learners received two texts. Before reading their texts, learners were given new words used in the texts with their equivalent L1 meaning. In other words, if learners' attention is not drawn to lexical items, they can focus on the content information. The dyads were asked to read their texts carefully and they were not allowed to see their partners'. Having finished reading their texts they had to retell descriptions to their partners. And finally, they were asked to come to a joint decision and provide their justifications.

The task with a focus on simple present tense was in the form of a dictogloss. In a dictogloss, a short passage is devised in which a structure has been focused on. The students listen to get a general idea of the text and then they jot down key words. Each dyad was asked to produce a single reconstructed text. It was a passage about an individual's daily activity with few unknown words.

Learners were presented the present continuous tense structure through two pictures. Each one depicted different daily activities. Each dyad was given the two pictures. They were not allowed to see the other dyad's picture. Participants were asked to negotiate and not down the differences which they specified between the pictures.

The last structural point was similar to present continuous tense task. The input was presented in the form of illustrations and each pair held a different picture in each dyad. The procedure was like that of the previous task.

The PPP model group received the same linguistic structures. While the task group engaged in task-based activities, the learners in the control group followed the PPP treatment. The target structure was introduced and learners practiced them in different exercises such as fill- in-the-gaps, multiple choice tests and drills, and finally produced them in activities such as role play.

\section{Results}

To establish whether the levels of homogeneity of learners between two groups in the grammar section and writing of the pretest, the analysis of covariance(ANCOVA)formula was performed before the study. Table 4.1 shows the results.

Table 4.1 Tests of Between-Subjects Effects

\begin{tabular}{llllll}
\hline Source & \multicolumn{2}{l}{ Type III Sum of } & & & \\
& Squares & df & Mean Square & F & Sig. \\
\hline Corrected Model & $365.417^{\mathrm{a}}$ & 2 & 182.708 & 8.845 & .001 \\
Intercept & 720.300 & 1 & 720.300 & 34.869 & .000 \\
group2 & 225.333 & 1 & 225.333 & 10.908 & .002 \\
group & 140.083 & 1 & 140.083 & 6.781 & .012 \\
Error & 929.583 & 45 & 20.657 & & \\
Total & 18170.000 & 48 & & & \\
Corrected Total & 1295.000 & 47 & & & \\
\hline
\end{tabular}

a. $\quad$ R Squared $=.282($ Adjusted R Squared $=.250)$

Table 4.2 Tests of Between-Subjects Effects 


\begin{tabular}{llllll}
\hline Source & \multicolumn{2}{l}{ Type III Sum of } \\
& Squares & df & Mean Square & F & Sig. \\
\hline Corrected Model & $66.042^{\mathrm{a}}$ & 2 & 33.021 & 23.060 & .000 \\
Intercept & 13.333 & 1 & 13.333 & 9.311 & .004 \\
group2 & 46.021 & 1 & 46.021 & 32.139 & .000 \\
group1 & 20.021 & 1 & 20.021 & 13.982 & .001 \\
Error & 64.438 & 45 & 1.432 & & \\
Total & 1148.000 & 48 & & & \\
Corrected Total & 130.479 & 47 & & & \\
\hline
\end{tabular}

a. $\mathrm{R}$ Squared $=.506($ Adjusted R Squared $=.484)$

According to table 4.1, the rate of significance in the grammar section of pretest is .012 . and according to table 4.2 , the rate of significance in the writing section of pretest is 001 .Since the rate of significance in both groups is greater than 0.05 , it would be concluded that two groups were homogenous in the pretest. As mentioned before, all of the learners were chosen with the same level of proficiency. Therefore, the results of the test showed that there were not significant differences among the groups in both pretests.

In order to determine which group (control or experimental) did better in the posttest, as table 4.3 illustrates, the mean pre-test writing score of the control group is 4 and the post-test mean is 5.54. This means that the participants did better in the post-test than in the pre-test. To see whether this difference is significant or not, a matched T-test was used.

Table 4.3 Paired Samples Statistics

\begin{tabular}{llllll}
\hline & & Mean & N & Std. Deviation & Std. Error Mean \\
\hline \multirow{2}{*}{ Pair 1 } & prewriting & 4.000 & 24 & 1.59 & 0.454 \\
& post writing & 5.542 & 24 & 1.1172 & .0 .322 \\
\hline
\end{tabular}

Table 4.4 shows the effect of instruction presented through PPP-oriented activity in the control group.as the table indicates, the $\operatorname{sig}=0.01$. It can be inferred that there is a meaningful difference between the pre-posttest writing tasks in the control group.

Table 4.4 paired sample statistics

\begin{tabular}{|c|c|c|c|c|c|c|c|c|}
\hline & & \multicolumn{5}{|c|}{ Paired Differences } & \multirow[b]{3}{*}{$\mathrm{t} \quad \mathrm{df}$} & \multirow{3}{*}{$\begin{array}{l}\text { Sig. } \\
\text { tailed) }\end{array}$} \\
\hline & & \multirow[b]{2}{*}{ Mean } & \multirow{2}{*}{$\begin{array}{l}\text { Std. } \\
\text { Deviation }\end{array}$} & \multirow{2}{*}{$\begin{array}{l}\text { Std. Error } \\
\text { Mean }\end{array}$} & \multicolumn{2}{|c|}{$\begin{array}{l}95 \% \text { Confidence } \\
\text { Interval of the } \\
\text { Difference } \\
\end{array}$} & & \\
\hline & & & & & Lower & Upper & & \\
\hline Pair 1 & $\begin{array}{l}\text { prewritting } \\
\text { postwritting }\end{array}$ & - -1.5417 & 1.711 & 0.496 & -2.378 & -0.454 & $-2.860 \quad 11$ & 0.010 \\
\hline
\end{tabular}

According to table 4.5, the participants' mean pre-test grammar score of the control group is 17.58and the post-test mean is 18.25. This means that the participants did better in the post-test than in the pre-test. To see whether this difference is significant or not, a matched T-test was used.

Table 4.5 Paired Samples Statistics

\begin{tabular}{llllll}
\hline & & Mean & N & Std. Deviation & Std. Error Mean \\
\hline Pair 1 & Pre grammar & 17.58 & 24 & 4.44 & 1.25638 \\
& post grammar & 18.25 & 24 & 3.27 & .66434 \\
\hline
\end{tabular}

The result of the analysis indicates that the difference was indeed significant.

Table 4.6 Paired Samples Test

Paired Differences

$95 \%$ Confidence Interval

Std. Std. Error of the Difference $\quad$ Sig. (2-

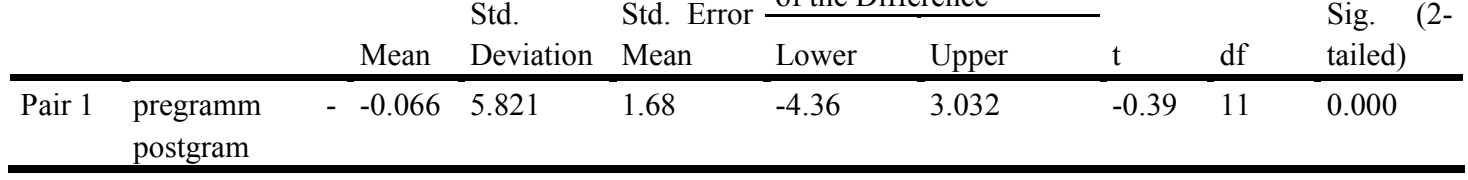


As table 4.7 illustrates, the mean pre-test writing score of the experimental group is 3.40 and the post-test mean is 4.50 . This means that the participants did better in the post-test than in the pre-test. To see whether this difference is significant or not, a matched T-test was used.

Table 4.7 Paired Samples Statistics

\begin{tabular}{llllll}
\hline & & Mean & N & Std. Deviation & Std. Error Mean \\
\hline Pair 1 & prewr & 3.40 & 24 & 1.59 & 0.454 \\
& postwr & 4.50 & 24 & 1.1172 & .0 .322 \\
\hline
\end{tabular}

To see whether this difference is significant or not, a matched T-test was used.as table 4.8 shows, there is a meaningful difference at 0.05 significance level.

Table 4.8 Paired Samples Test

\begin{tabular}{|c|c|c|c|c|c|c|c|c|c|}
\hline & & \multicolumn{5}{|c|}{ Paired Differences } & \multirow[b]{3}{*}{$\mathrm{t}$} & \multirow[b]{3}{*}{$\mathrm{df}$} & \multirow{3}{*}{$\begin{array}{l}\text { Sig. } \\
\text { tailed) }\end{array}$} \\
\hline & & \multirow[b]{2}{*}{ Mean } & \multirow{2}{*}{$\begin{array}{l}\text { Std. } \\
\text { Deviation }\end{array}$} & \multirow{2}{*}{$\begin{array}{l}\text { Std. Error } \\
\text { Mean }\end{array}$} & \multicolumn{2}{|c|}{$\begin{array}{l}95 \% \text { Confidence } \\
\text { Interval of the } \\
\text { Difference }\end{array}$} & & & \\
\hline & & & & & Lower & Upper & & & \\
\hline Pair 1 & $\begin{array}{l}\text { prewr } \\
\text { postwr }\end{array}$ & --1.5417 & 1.711 & 0.496 & -2.378 & -0.454 & -2.860 & 11 & 0.030 \\
\hline
\end{tabular}

As table 4.9 illustrates, the mean pre-test grammar score of the experimental group is greater than that of the pre-test. To see whether this difference is significant or not, a matched T-test was used.

Table 4.9 Paired Samples Statistics

\begin{tabular}{llllll}
\hline & & Mean & N & Std. Deviation & Std. Error Mean \\
\hline Pair 1 & pregramm & 15.58 & 24 & 4.44 & 1.25638 \\
& postgram & 19.25 & 24 & 3.27 & 0.66434 \\
\hline
\end{tabular}

According to table 4.10, the amount of significance is 0.66 which indicate that although participants in the experimental group did better in the grammar section of the post-test compared to their pre-test performance, this difference is not significant.

Table 4.10 Paired Samples Test

\begin{tabular}{|c|c|c|c|c|c|c|c|c|}
\hline & \multicolumn{5}{|c|}{ Paired Differences } & \multirow[b]{3}{*}{$\mathrm{t}$} & \multirow[b]{3}{*}{ df } & \multirow{3}{*}{$\begin{array}{l}\text { Sig. (2- } \\
\text { tailed) }\end{array}$} \\
\hline & \multirow[b]{2}{*}{ Mean } & \multirow{2}{*}{$\begin{array}{l}\text { Std. } \\
\text { Deviatio } \\
\mathrm{n}\end{array}$} & \multirow{2}{*}{$\begin{array}{l}\text { Std. } \\
\text { Error } \\
\text { Mean }\end{array}$} & \multicolumn{2}{|c|}{$\begin{array}{l}95 \% \text { Confidence } \\
\text { Interval of the } \\
\text { Difference }\end{array}$} & & & \\
\hline & & & & Lower & Upper & & & \\
\hline $\begin{aligned} & \text { Pair } 1 \text { pregramm } \\
& \text { postgram }\end{aligned}$ & $\begin{array}{l}-- \\
0.066\end{array}$ & 5.821 & 1.68 & -4.36 & 3.032 & -0.39 & 11 & 0.669 \\
\hline
\end{tabular}

\section{Discussion \& Conclusion}

The results of the findings of the present paper indicated that in an EFL setting, task-based approaches was effective. That is, learners in experimental group performed better than those who were in the control group. These results seem to support the conclusions from several previous studies in the EFL context (Ellis, 2000; Kim, 2009; Willis, 1998; Vilches, 2003;Storch, 2001; Mayo, 2002 ;Skehan, 1996; Ellis, 2003; Littlewood;2004; Nunan, 2004) to name a few, proposing that task has a significant effect on learners' performance.

The current study aimed to examine whether task-based activities bear any superiority to other structurally oriented approaches. Another more specific question was that if task-oriented activities are proved to be more efficient in developing learners' interlanguage, what areas of language are more likely to benefit more from this approach: a 
productive written activity or a grammar recognition test? The results of the study show that task group demonstrated development in their writing task. However, the results of the grammar section is somewhat ironic in the task group. Tis does not fully correspond with initial researchers' presupposition who assumed that grammar instruction through taskbased activities can help learners internalize structural points more efficiently. Plausible explanation for this performance may be attributed to the nature of the posttest questions; while the instructional activities during the sessions in the task group catered to lead to implicit learning, the test called for the explicit knowledge of the learners in the control group. Moreover, most of the activities in the control group were explicit in nature and targeted participants' explicit rather than implicit learning.

What this study implies is the fact that where developing explicit is the paramount concern of the learners, the reliance can be toward the PPP model and when learners need to form a good command of implicit knowledge which enables them to function efficiently in meaning-driven context, TBLT can be of immense help.

Fuente (2006) investigated the efficacy of task-based approaches compared to PPP model. Although the immediate post-test did not reveal any significant difference between the groups, participants in the task group outperformed in the delayed post-test.

In the current study, the results are not in line with those of Fuente at least where structure was not concerned; the participants' performance in the writing task of the test in the PPP group was not to differ from that of task-based group in any significant way. In the grammar section of the test the results reveal the superiority of task based performance compared to that of control group.

Vilches (2003) points out that replacing class activities with task-based activities had a significant effect on the learners' language proficiency. Learners were shown to have improved significantly in their productive skills of writing and speaking. The results of the writing section of the task group are in oppose with his observations.

\subsection{Implication}

The current study suggest that language teachers and syllabus designers can make use of task as a unit of activity which caters for fluency and implicit learning. Therefore, It should draw learners' primary attention to meaning and only peripherally to form. In pursuing this goal task-related activities should be introduces before form instruction. Once learners worked hard to communicate meaning, practiced language in a meaningful context, and realized the existing gap in what they wanted to say and the way they should say it, they would be ready to receive those forms in a more explicit manner.

\section{References}

Allwright, D. (1975). Problems in the study of the language teachers' treatment of learner error. In M. Burt \& H.Dulay (Eds.). New directions in second language learning, teaching, and bilingual education: TESOL 75 (pp. 96-109). Washington, DC: TESOL.

Brown, H. D. (2001). Teaching by principles. New York: Pearson Education Company.

Dulay, H. \& Burt, M. (1973). Should we teach children syntax? Language Learning, 24, 245-258.

Ellis, R. (2001). Investigating form- focused instruction. Language learning, 51(1), 1-46.

Ellis, R. (2003). Task-based language learning and teaching. Oxford University Press, Oxford (2003).

Ellis, R. (2006). Current issues in the teaching of grammar: An SLA perspective. TESOL Quarterly, 40(1), 83-107.

Foster, P., \& Skehan, P. (1999). The influence of source of planning and focus of planning on task-based performance. Language Teaching Research, 3, 215-247.

Fuente, M. J. (2006). Classroom L2 vocabulary acquisition: investigating the role of pedagogical tasks and formfocused instruction. Language Teaching Research, 10 (3), 263-295. Retrieved March 10, 2007 from http://lrc.cornell.edu/events/past/2006-2007/fuentes.pdf.

Gass, S., (1997). Input, interaction and the second language learner. Erlbaum, Mahwah, NJ.

Hatch, E. (1978). Second Language Acquisition. Rowley, Mass: Newbury House.

Kim,Y. (2004). The effects of task complexity on learner-learner interaction. System, 37(2), 254-268.

Krashen, S. (1982). Principles and Practice in Second Language Acquisition. Oxford: Pergamon.

Krashen, S. (1985). The input hypothesis: issues and implications. Oxford: Pergamon Press.

Krashen, S. \& Terrell,T. (1983). The natural approach: Language Acquisition in the Classroom.Oxford: Pergamon.

Krashen, S. (1998). Comprehensible output? System, 26, 175-182.

Krashen, S. (1994). The input hypothesis and its rivals. In N. Ellis (Ed.), Implicit and Explicit Learning of Language. London: Academic Press.

Littlewood, w. (2004). The task based approach: some questions and suggestions. ELT journal, 58(4).

Littlewood, W. (2007) Communicative and task-based language teaching in East Asian classrooms. Language

Teaching, 40, 243249. 
Long, M., (1983). Native speaker/ non-native speaker conversation and the negotiation of comprehensible input. Applied Linguistics, 4, 126-141.

Long, M. (1991). "Focus on Form: A design feature in language teaching Methodology". In Ginsberg, K. \& Kramsch, C. (Eds), Foreign Language Research in Cross-Cultural Perspective (pp.39-52).

Long, M. (1996). "The role of the linguistic environment in second language acquisition". Handbook of second language acquisition. San Diego: Academic Press.

Long, M. (1997). Construct validity in SLA research: a response to Firth and Wagner. Modern Language Journal, 81, 318-323.

Long, M., \& Robinson, P. (1998). Focus on form: theory, research, process. In C. Doughty \& J. Williams

(Eds.): Focus on form in Classroom Second Language Acquisition. (pp.15-41). Cambridge: Cambridge University Press.

Mayo, G. (2002). The effectiveness of two form focused tasks in advanced EFL pedagogy, International Journal of Applied Linguistics, 12(1), 156-175.

Nassaji, H., \& Fotos, S. (2004). Current developments in research on the teaching of grammar. Annual Review of Applied Linguistics, 24, 126-145.

Nunan, D. (2004). Task based language teaching. Cambridge University Press, Cambridge (2004).

Pica, T. (1994). Questions from the language classroom: research perspective. TESOL Quarterly, 28, 49-79.

Prabhu, N.S. (1987). Second Language Pedagogy. Oxford: Oxford University Press.

Skehan, P. (1998). A cognitive approach to language learning. Oxford: Oxford University Press.

Storch, N. (2001). An investigation into the nature of pair work in an ESL classroom and its effect on grammatical development Unpublished doctoral dissertation: the University of Melbourne.

Vilches, C. L. M. (2003). Task based language teaching: The case of EN 10. RELC, 34 (1), 82-99.

White, L. (1987). Against comprehensible input: the input

Willis, D. \& Willis, J. (2007) .Doing Task-based Teaching. Oxford: Oxford University Press

Willis, J. (1996). A Framework for Task-based Learning. Harlow: Longman.

Willis, J. (1998). A Framework for Task-Based Learning. Longman: de Henseler Books. 